\title{
Reconstrução do LCA com o uso dos tendões dos músculos flexores mediais do joelho e fixação femoral com o sistema de Rigidifix ${ }^{\circledR}$ - Relato Preliminar
}

Anterior cruciate ligament reconstruction using double hamstrings tendon graft and the femoral fixation by Rigidifix ${ }^{\circledR}$ - Preliminary Study

\section{RESUMO}

O autor descreve a técnica de reconstrução do LCA no tratamento das instabilidades anterior do joelho, utilizando os tendões dos músculos flexores mediais do joelho (semitendíneo e grácil), fixados no fêmur pelo sistema de Rigidfix ${ }^{\circledR}$; e na tíbia, com parafuso de interferência absorvível, através de um estudo preliminar de 54 joelhos operados.

$\mathrm{Na}$ avaliação final pela escala de Lysholm os pacientes evoluíram de 46 pontos no pré-operatório para 92 pontos no pósoperatório.

Descritores: Ligamento cruzado anterior; Joelho; Reconstrução.

\section{INTRODUÇÃO}

As técnicas de reconstrução do LCA têm sido constantemente aperfeiçoadas nos últimos anos, mas ainda não temos certeza absoluta de qual deverá ser o enxerto e o método de fixação ideal.

Vários substitutos intraarticulares do LCA vêm sendo descritos, utilizando os mais variados enxertos autólogos, heterólogos e sintéticos. Entre os enxertos autólogos ultimamente tem ganhado preferência dos autores o terço central do ligamento patelar ${ }^{(1,4,12)}$, o semitendíneo triplo e semitendíneo e grá-

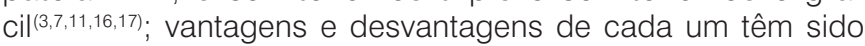
descritas e avaliadas.

\section{SUMMARY}

The author describes the reconstruction technique of the anterior cruciate ligament reconstruction using the hamstrings tendon (semitendinosus and gracilis) in the management of anterior instabilities of the knee joint. Rigidfix ${ }^{\circledR}$ system is used to fix the graft on the femur and an absorbable interference screw was used for tibial fixation in a preliminary study in 54 knees.

The final evaluation based on Lysholm score showed an improvement from 46 (preoperative) to 92 (postoperative).

Keywords: Anterior cruciate ligament; Knee; Reconstruction.

\section{INTRODUCTION}

Reconstruction techniques of the anterior cruciate ligament (ACL) have been continuously improved. The ideal graft and fixation method, however, have not yet been defined.

Several intraarticular substitutes of ACL have been described, including autologous, heterologous, and synthetic grafts. As for autologous grafts authors have given their preference for the central third of the patellar ligament ${ }^{(1,4,12)}$, and triple semitendinosus, and semitendinosus and gracilis tendons $(3,7,11,16,17)$. Their advantages and disadvantages have been described and evaluated elsewhere.
Trabalho realizado no Orthoservice - Pronto Socorro Ortopédico

1 - Médico Ortopedista

Endereço para correspondência: Av. Tívoli, 433 - V. Betânia - Cep: 12245-230 São José dos Campos - SP - e-mail: orthoservice@orthoservice.com.br cacury@iconet.com.br

Trabalho recebido em 02/02/2003. Aprovado em 10/08/2004
Work performed at the Orthoservice - Orthopedic Emergency Room 1 - Orthopaedist Doctor

Address: Av. Tívoli, 433 - V. Betânia - CEP: 12.245-230 - São José dos Campos/SP orthoservice@orthoservice.com.br

cacury@iconet.com.br 
Outro ponto importante ${ }^{(10,15)}$ e bastante discutido tem sido os métodos de fixação dos enxertos.

O objetivo deste trabalho não é avaliar a técnica cirúrgica em longo prazo, mas fazer um estudo preliminar.

\section{MATERIAL E MÉTODO}

No período de outubro de 2001 a outubro de 2002, foram operados 54 joelhos de 54 pacientes, submetidos à reconstrução do LCA com o uso dos tendões dos músculos flexores mediais do joelho (semitendíneo e grácil), fixados no fêmur através do sistema de Rigidfix ${ }^{\circledR}$; e na tíbia, com o parafuso de interferência absorvivel no Orthoservice em São José dos Campos, SP.

Dos 54 joelhos, 50 foram do sexo masculino e quatro do sexo feminino.A idade variou de 16 a 50 anos (média de 27 anos): 30 tiveram o joelho direito operado e 24 foram submetidos à operação no esquerdo.

A operação foi realizada por via artroscópica e foram encontradas as seguintes lesões associadas: 34 do menisco medial; sete do menisco lateral; cinco de ambos os meniscos; quatro lesões condrais femorais. Observamos apenas quatro lesões isoladas do LCA.

\section{TÉCNICA CIRÚRGICA}

Após os procedimentos convencionais da cirurgia do joeIho, realizamos incisão de pele e tecido celular subcutâneo de quatro $\mathrm{cm}$ na face anteromedial do terço proximal da perna do lado acometido, na região mais posterior possível, da inserção dos tendões dos músculos flexores mediais. Dissecção cuidadosa e identificação dos tendões dos músculos semitendíneo e grácil; reparação e desinserção através de um extrator de tendão. Os tendões são preparados na mesa auxiliar, sendo colocados um sobre o outro e dobrando-os sobre um fio de Ethibond $^{\circledR}$ 5. Em seguida, as extremidades dos tendões são suturadas, unindo-os através de um chuleio com Ethibond ${ }^{\circledR} 5$. $\mathrm{Na}$ extremidade proximal dos enxertos são realizados dois pontos com Vicril $^{\circledR}$ 0 , sendo realizados intervalo de $\mathrm{um} \mathrm{cm}$ entre cada um deles e a extremidade proximal do enxerto, para permitir futuramente a passagem dos pinos de Rigidfix ${ }^{\circledR}$ através do enxerto (Figura 1).

Através da via de acesso pela técnica de triangulação convencional dos procedimentos artroscópicos do joelho, são realizadas o tratamento das lesões intrínsecas associadas e ressecção dos restos do LCA.

Nos pontos anatômicos de origem e inserção do LCA original, são feitos os túneis tibial e femoral com diâmetro igual ao do enxerto.
Another important and widely discussed point ${ }^{(10,15)}$ is the graft fixation method.

The present study does not aim to evaluate long-term results for the surgical technique. It is a preliminary study.

\section{MATERIAL AND METHODS}

From October 2001 to October 2002, 54 knee joints from 54 patients were submitted to ACL reconstruction with tendons of the medial flexor muscles of the knee joint (semitendinosus, gracilis) fixed on the femur with the Rigidfix ${ }^{\circledR}$ system and on the tibia with an absorbable interference screw at the Orthoservice in São José dos Campos, SP.

Fifty male and four female patients aged 16 to 50 years (mean age: 27 years) were included into the study. The right and the left knee joints were operated in 30 and 24 cases, respectively.

Surgery was carried out through the arthroscopic route and the following associated lesions were found: medial meniscus in 34; lateral meniscus in 7; both menisci in 5; femoral chondral lesion in 4. Isolated lesion of the anterior cruciate ligament was found in only 4 cases.

\section{SURGICAL TECHNIQUE}

Following conventional procedures of knee joint surgery, a 4$\mathrm{cm}$ incision of skin and subcutaneous cellular tissue was performed on the anteromedial face of the proximal third of the affected leg as posterior as possible from insertion of the tendon of medial flexor muscles. The following steps were carried out: careful dissection and identification of tendons of semitendinosus and gracilis muscles; repair and disinsertion through a tendon extractor. Tendons were prepared on the accessory table and were put one on the other; tendons were then folded over a Ethibond ${ }^{\circledR} 5$ thread. Two stitches were made with Vicril ${ }^{\circledR} 01 \mathrm{~cm}$ away from the proximal end of grafts so as to allow insertion of Rigi$d f i{ }^{\circledR}$ pins through the graft (Figure 1).

Associated intrinsecal lesions were treated and ACL rests were excised through the conventional triangulaton route for arthroscopic procedures of the knee joint.

Tibial and femoral tunnels were performed at the anatomical points of origin and insertion of the ACL. The diameter of these tunnels were equal to that of the graft.

With the appropriate femoral guide we inserted the Rigidfix ${ }^{\circledR}$ guide-pins through two perforations from the outside to the inside of the tunnel (Figure 2).

The graft was inserted from tibia to femur where it was fixed with two pins of Rigidfix ${ }^{\circledR}$. Pretensioning was carried out in situ. Tibial fixation was performed with an absorbable interference screw of a diameter equal to or, when needed, greater than that of the tunnel with the knee joint in extension (Figure 3). 
Com guia femoral apropriado fazemos a passagem dos pinos guia do sistema de Rigidfix ${ }^{\circledR}$, através de duas perfurações de fora para dentro do túnel (Figura 2).

Realizamos a passagem do enxerto da tíbia para o fêmur. Fixamos com os dois pinos de Rigidfix ${ }^{\circledR}$ no fêmur, realizamos o pré tensionamento "in situ". A fixação tibial ocorre com parafuso de interferência absorvível do diâmetro do túnel ou um número maior, se necessário, estando o joelho em extensão (figura 3).

Realizamos os testes de avaliação de estabilidade articular convencionais, colocamos dreno de aspiração por 24 horas, fechamento da ferida operatória e imobilização tipo brace.

Liberamos para carga parcial a partir da alta hospitalar após 24 horas e exercícios isométricos e flexo-extensão são realizados a partir do $4^{\circ}$ dia de pós-operatório.

Os pontos são retirados com 15 dias e os pacientes são encaminhados para um programa de reabilitação em clínicas apropriadas.

\section{RESULTADOS}

Todos os 54 pacientes foram operados e acompanhados pelo autor. O tempo de seguimento variou de seis a 18 meses, com média de 12 meses.

Através da escala de Lysholm a avaliação pré-operatória foi de 46 pontos, evoluindo para 92 pontos no pós-operatório, sendo considerados excelentes em 28 joelhos (52\%), bom em 20 joelhos (37\%), regular em quatro joelhos (7\%) e ruim em dois joelhos (4\%).

Como complicações tivemos um caso de infecção superficial que regrediu com uso de antibioterapia específica e um caso de ruptura do enxerto no $5^{\circ}$ mês de pós-operatório, após queda acidental do paciente. Tivemos também, redução nos últimos $15^{\circ}$ de flexão, em dois pacientes e outros dois casos com dor nas atividades esportivas.

Obtivemos dois casos de mau resultado com recidiva da instabilidade, sendo um caso por queda acidental do paciente e outro por afrouxamento progressivo do enxerto e sintomatologia correspondente.

Os casos que necessitaram de avaliação radiológica, através de ressonância magnética, mostraram-se com excelente

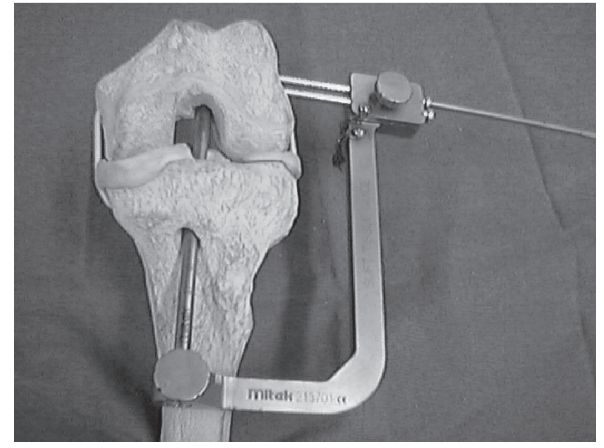

Figura 2 - Sistema de Rigidfix ${ }^{\circledR}$

Figure 2 - Rigidfix ${ }^{\circledR}$ System

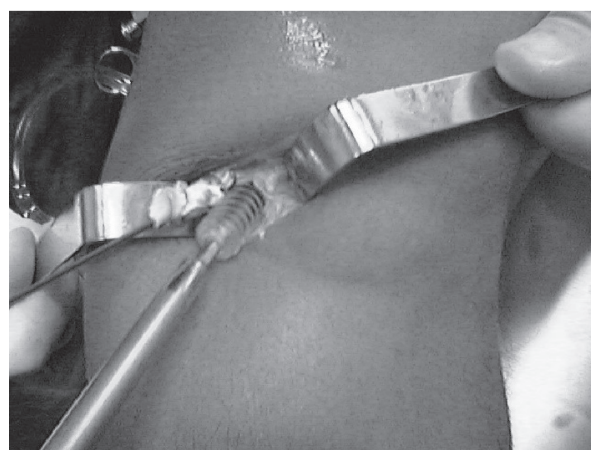

Figura 3 - Fixação tibial parafuso absorvível

Figure 3 - Tibial fixation with an absorbable screw

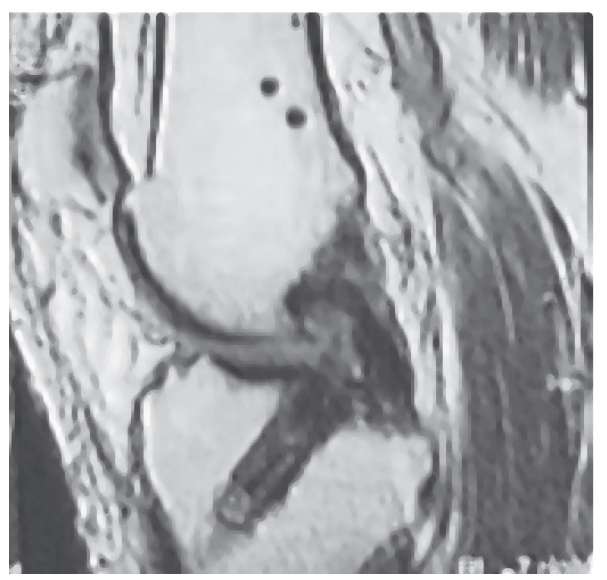

Figura 4 - Ressonância magnética

Figure 4 - Magnetic Resonance Imaging
Conventional joint stability tests were carried out, a drainage tube was inserted and kept in place for $24 \mathrm{~h}$, surgical wound was closed, and brace-type immobilization was used.

Partial load was allowed $24 \mathrm{~h}$ following hospital discharge, and isometric and flexion-extension exercises were carried out from the 4th postoperative day on.

Stitches are removed 15 days following surgery and patients are referred to specialized clinics for a rehabilitation program.

\section{RESULTS}

All 54 patients were operated and followed by the author. Follow-up ranged from 6 to 18 months (mean follow-up: 12 months).

Preoperative evaluation showed a score of 46 upon Lysholm scale versus 92 following surgery. The following results were obtained: excellent in 28 knee joints (52\%), good in 20 knee joints (37\%), regular in 4 knee joints (7\%), and poor in 2 knee joints (4\%).

The following complications developed: a superficial infection that was resolved with specific antibiotic therapy in one case; graft rupture following an accidental fall in one case five months after surgery; a decrease in the last flexion $15^{\circ}$ in two cases; and pain upon physical exercises in two cases.

A poor result was obtained in two cases with instability recurrence due to accidental fall in one case and progressive loosening of the graft and corresponding symptoms.

In cases where magnetic resonance imaging was used, an excellent pattern of images was obtained with few artifacts. Therefore, a detailed analysis of all joint structures was possible. The same is not true for patients in whom metallic fixation is used (Figures 4 and 5). 
padrão de imagens e com poucos artefatos, permitindo analise detalhada de todas as estruturas articulares, ao contrário, dos métodos de fixação metálicas (figura 4 e 5).

\section{DISCUSSÃO}

O enxerto quádruplo dos tendões dos músculos flexores mediais do joelho (semitendíneo e grácil), tem sido, uma opção cada vez mais comum, devido às complicações do uso do terço central do ligamento patelar. Estudos biomecânicos demonstraram não haver grandes diferenças entre os dois enxertos.

Inicialmente Puddu(13) em 1980, usou

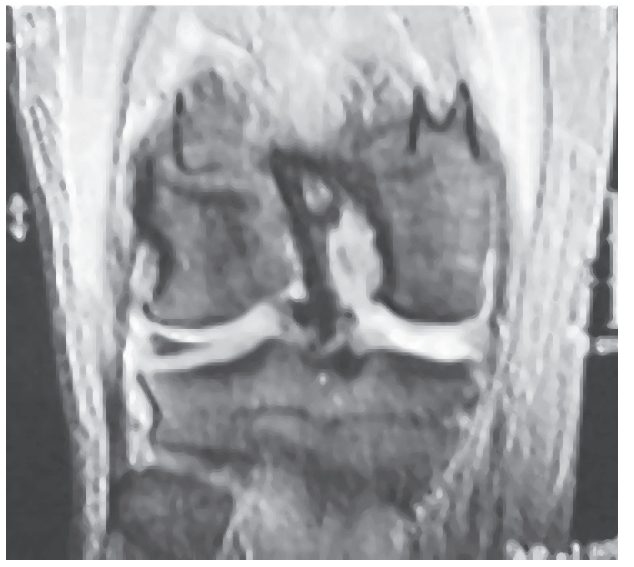

Figura 5 - Ressonância magnética

Figure 5 - Magnetic Resonance Imaging sical behavior of both grafts is similar.

In 1980 Puddu(13) was the first to use the tendons of medial flexor muscles. In our country, Gomes e Marczyk ${ }^{(5)}$ used this graft in 1981.

Camanho and Olivi(2) used a similar technique with Endobutton ${ }^{\circledR}$ fixation on the femur in 1996.

Krause et a/(9). suggested the use of pretensioning to reduce the Endobuttonâ system elasticity in 1998.

In 2001 Severino et a/(14) and col. published a similar technique as far as graft use is concerned.

They used, however, "BoneMuch ${ }^{\circledR}$ os tendões dos músculos flexores mediais e, em nosso meio, Gomes e Marczyk ${ }^{(5)}$, também o fizeram em 1981. Camanho e Olivi $^{(2)}$ utilizaram a técnica semelhante fixados com Endobutton ${ }^{\circledR}$ no fêmur, em 1996.

Krause et al. ${ }^{(9)}$, em 1998, sugeriram o pré tensionamento do sistema Endobutton ${ }^{\circledR}$.

Severino et al. ${ }^{(14)}$, em 2001, também publicaram técnica semelhante com relação à utilização dos enxertos, porém utilizou o parafuso de "BoneMulch ${ }^{\circledR}$ " para fixação femoral e "WasherLoc $^{\circledR}$, na tíbia com bons resultados.

Zekcer et al. ${ }^{(18)}$, ainda em 2001, também apresentaram técnica semelhante, entretanto fixou o enxerto no fêmur pelo método de Transfix ${ }^{\circledR}$, em estudo preliminar, com bons resultados.

Gali et al. ${ }^{\left({ }^{6}\right)}$, em 2002, apresentaram o uso dos tendões dos músculos flexores mediais do joelho, de forma quádruplo fixado com parafusos de interferência metálicos, com excelentes resultados.

A técnica que preconiza o sistema de fixação femoral através do Rigidfix ${ }^{\circledR}$ utiliza dois pinos transversos aos enxertos e ao túnel femoral, enquanto o sistema de Transfix ${ }^{\circledR}$ utiliza apenas um pino, além de ter uma curva de aprendizado maior.

Esta técnica ainda previne o risco de fratura da cortical posterior do fêmur, que poderá ocorrer com a utilização do terço central do ligamento patelar fixados com parafusos de interferência.

Ainda devemos considerar a redução do efeito "limpador de pára-brisa" ${ }^{(6)}$, que ocorre com o sistema Endobutton ${ }^{\circledR}$, uma vez que, o sistema Rigidfix ${ }^{\circledR}$, fixa o enxerto femoral de forma transversa e "in situ", não permitindo mobilidade entre a extremidade do enxerto e o sistema de fixação.

Acreditamos que o parafuso de interferência absorvível na tíbia possa promover algum grau de afrouxamento do conjunto, portanto, sempre que possível, utilizamos parafuso de um número maior ao diâmetro do túnel tibial.

O percentual de sucesso da operação foi coincidente com a literatura ${ }^{(2,6,14,18)}$.

A reabilitação permite ser mais agressiva, conforme descrita por Howell e Gottilieb ${ }^{(8)}$, devido a um quadro menos doloroscrew for femoral fixation and "WasherLoc ${ }^{\circledR}$ for tibial fixation with good results.

In a preliminary study Zekcer et al(18) and col. used a similar technique also in 2001. However, they used the Transfixâ method to fix the graft on the femur with good results.

Gali et al(6) described the quadruple use of tendons of the medial flexor muscles of the knee and fixation with metallic interference screws with excellent results in 2002.

The technique recommending the use of Rigidfix ${ }^{\circledR}$ for femoral fixation uses two pins across the graft and femoral tunnel while the Transfixâ system uses only one pin and requires a longer training.

This technique prevents the risk for fracture of the posterior cortical of the femur.

However, it can still occur when the central third of the pateIlar ligament is fixed with interference screws.

In addition, one must take into account the decrease in the "windshield wiper effect"(6) associated with the Endobutton ${ }^{\circledR}$ system since the Rigidfix ${ }^{\circledR}$ system fixes the femoral graft transversally and "in situ", thus preventing mobility between the graft end and the fixation system.

We believe that the absorbable interference screw on tibia can lead to loosening of the set. Therefore, whenever possible, we use a screw of a greater diameter than that of the tibial tunnel.

The success rate of surgery was similar to that reported in literature ${ }^{(2,6,14,18)}$.

Rehabilitation can be more aggressive as described by Howell and Gottilieb(8) due to less painful condition following surgery and less morbidity in the donor area.

\section{CONCLUSIONS}

The present study showed that the use of Rigidfix ${ }^{\circledR}$ for tendon fixation with no interface between elements in the femur led to $92 \%$ of excellent and good results, low rates of complications, a low learning curve, good visualization of joint structures upon magnetic resonance imaging, as necessary. 
so, no pós-operatório e menor morbidade na área doadora quando comparado à reconstrução do ligamento cruzado anterior utilizando como enxerto o terço central do ligamento patelar ${ }^{(15)}$.

\section{CONCLUSÕES}

A nossa casuística apresentou, utilizando a fixação tendínea com o sistema de Rigidfix ${ }^{\circledR}$, sem interface entre os elementos no fêmur, 92\% de excelentes e bons resultados, baixos índices de complicações, baixa curva de aprendizado, boa visualização das estruturas articulares através de ressonância magnética, quando necessárias.

\section{REFERÊNCIAS BIBLIOGRÁFICAS}

1. Aglietti P, Buzzi R, D'Andria S, Zaccherotti G. Long-term study of anterior cruciate ligament reconstruction for chronic instability using the central onethird patellar tendon and lateral extraarticular tenodesis. Am J Sports Med 20: 3845, 1992

2. Camanho GL Olivi R O uso do tendão do músculo semitendíneo fixo com "Endobutton ${ }^{\circledR}$ " no tratamento das instabilidades anteriores do joelho. Rev Bras Ortop 31:369-372, 1996

3. Cho KO. Reconstruction of anterior cruciate ligament by semitendinosus tenodesis. J Bone Joint Surg Am 57:608-612, 1975.

4. Clancy WG, Nelson DA, Reider B et al. Anterior cruciate ligament reconstruction using one-third of the patellar ligament, augmented by extraarticular tendon transfer. J Bone Joint Surg Am 64:352-359, 1982.

5. Ellera Gomes JL, Marczyk LR. Reconstrução dos ligamentos cruzados do joelho com o tendão duplo do semitendinoso. Rev Bras Ortop 16:128-132 1981.

6. Gali JC, Adad, MAH, Mod MSB. Reconstrução do ligamento cruzado anterior com tendões flexores quádruplos e parafusos de interferência metálicos. Rev Bras Ortop 37:240-246, 2002.

7. Gomes JL, Marczyk LR. Anterior cruciate ligament reconstruction with a loop or double thickness of semitendinosus tendon. Am J Sports Med 12:199-203, 1984

8. Howel S, Gottilieb J. Endoscopic fixation of a doublé-looped semitendinous and gracilis ACL graft using Boné Mulch screw. Oper Tech Orthop 6:152-160, 1996.

9. Krause R, Camanho G, Krause M. Reconstrução do LCA: pré-tensionamento "in situ" do semitendíneo triplo. Rev Bras Ortop 33:363-367, 1998.
10. Kurosaka M, Shinichi Y, Jack TA. A biomechanical comparison of different surgical techniques of graft fixation in anterior cruciate ligament reconstruction. Am J Sports Med 3:225-229, 1987.

11. Lipscomb AB, Johnston RK, Snyder RB et al. Evaluation of hamstring strength following use of semitendinosus and gracilis tendons to reconstruct the anterior cruciate ligament. Am J Sports Med 10:340-342, 1982

12. O'Brien SJ, Warren RF, Pavtov $\mathrm{H}$ et al. Reconstruction of the chronically insufficient anterior cruciate ligament with the central third of the patellar ligament. J Bone Joint Surg Am 73:278-286, 1991.

13. Puddu G. Method for reconstruction of the anterior cruciate ligament using semitendinous tendon. Am J Sports Med 8:402-404, 1980

14. Severino NR, Camargo OPA, Aihara T, Cury RPL, Oliveira VM, Nishihara C Utilização do parafuso "Bone Mulch" na reconstrução do ligamento cruzado anterior com tendões dos músculos semitendinoso e grácil. Rev Bras Ortop 36:79-83, 2001.

15. Steiner ME, Aaron TH, Charles $\mathrm{HB}$ et al. Anterior cruciate ligament graft fixation. Comparison of hamstring and patellar tendon grafts. Am J Sports Med 2:240-247, 1994.

16. Zaricznyj B. Reconstruction of the anterior cruciate ligament of the knee using a doubled tendon graft. Clin Orthop 220:162-175, 1987

17. Zarins $\mathrm{B}$, Rowe $\mathrm{CR}$. Combined anterior cruciate-ligament reconstruction using semitendinous tendon and iliotibial tract. J Bone Joint Surg Am 68: 160-177, 1986.

18. Zekcer A, Carneiro ACl, Minervini S, Carneiro Filho M. "TransFix" do de fixação femoral dos tendões flexores na reconstrução do LCA. Relato preliminar. Rev Bras Ortop 36: 340-343, 2001. 